\title{
The Relationship of the Different Editions of Daniel: A History of Scholarship
}

Currents in Biblical Research 2015, Vol. 13(2) 175-190

(C) The Author(s) 2014

Reprints and permissions: sagepub.co.uk/journalsPermissions.nav DOI: 10.1 I77/|476993X1452443 | cbi.sagepub.com (SAGE

\section{Amanda M. Davis Bledsoe}

Ludwig Maximilian University of Munich, Germany

\begin{abstract}
The book of Daniel has one of the more complicated textual histories of any biblical book. It is written in two languages (Hebrew and Aramaic), and the content drastically differs in the two halves of the book (stories in chs. $1-6$ and visions in chs. 7-12). Perhaps the most difficult attribute to explain, however, is that it is preserved in several distinct editions, which at times vastly diverge from one another. These are the Masoretic edition in Hebrew and Aramaic, and the Old Greek and Theodotionic editions in Greek. The relationship of these three editions of the book of Daniel has been disputed for more than two hundred years, and a scholarly consensus has not yet been reached. This overview surveys the history of scholarship on the different editions in hopes that future studies on the book of Daniel will give the OG edition equal status with the MT edition of the book, which it has hitherto not received.
\end{abstract}

\section{Keywords}

Book of Daniel, Masoretic Text (MT), Old Greek (OG), Septuagint (LXX), Theodotion, Aquila, Symmachus, double literary editions, Aramaic Daniel

\section{Introduction}

The book of Daniel has a very complicated textual history. Although it is the latest book contained in the Hebrew Bible (probably completed around $167 \mathrm{BCE}$ ), it has an extensive pre-history, with parts of the book dating back to the Babylonian period some four hundred years earlier. The book of Daniel is exceptional among biblical books in that it is preserved in two Semitic languages: Hebrew

\section{Corresponding author:}

Amanda M. Davis Bledsoe, Ludwig Maximilian University of Munich, Geschwister-Scholl-Platz I, Munich, Germany 80539.

Email: Amanda.Bledsoe@evtheol.uni-muenchen.de 
(chs. 1:1-2:4a, 8:1-12:13) and Aramaic (chs. 2:4b-7:28). The book is further divided into two sections: the court narratives of the first half (chs. 1-6), and the visions of the latter half (chs. 7-12). It is typically argued that the stories of the first half originally circulated independently, but subsequently came together around the figure of Daniel and his three companions, to which the visions of the second half were later added (Montgomery 1927: 36; Koch 1980: 18-19, 75; Albertz 1988: 159-60; Wills 1990: 144-52; Collins 1993: 37-38; Davies 1998: 40-55; McLay 2005: 318-23). It is, however, often difficult to distinguish between the earlier versus later layers of the book, since the division in language does not align with the division of content (Davies 1998: 34-39).

Perhaps the primary difficulty in unraveling the composition history of the book of Daniel is that it is preserved in at least three distinct editions: the Hebrew/Aramaic Masoretic edition (MT), as well as two Greek editions-the Old Greek (OG) and Theodotion. In antiquity it is likely that other editions of the book also existed, as indicated by Origen's Hexapla, which also contains Aquila and Symmachus, but these are known today only from fragments. Concerning the three surviving editions, there is little scholarly consensus regarding their relationship. For the majority of the chapters of Daniel, the MT, the OG, and the Theodotionic editions preserve similar forms of the narratives, with only minor additions or alterations. This is not the case, however, for chs. 4-6, which display two clearly distinct editions of the narratives: the MT and Theodotion generally align, while the OG diverges greatly. Even more interesting is that in these chapters there is no consistent relationship between the MT and Theodotion on the one hand, and the OG edition on the other. Chapters 4 and 6 of the OG are much longer than their MT/Theodotion counterparts, whereas ch. 5 in the OG is substantially shorter than the MT/Theodotion editions. This matter becomes even more complicated in that elsewhere the OG and Theodotion align against the MT, in that the two Greek editions include several 'additions' to Daniel that are absent from the MT. These are 'The Prayer of Azariah and the Song of the Three Youths' (inserted between Dan. 3 vv. 23 and 24) and 'Susanna' and 'Bel and the Dragon'.

Before turning to the history of scholarship on the different editions of Daniel, I first provide an introduction to each edition.

\section{The Different Editions of Daniel}

\section{(I) Masoretic Edition}

The MT edition of Daniel consists of twelve chapters with Dan. 1:1-2:4a and 8:1-12:13 in Hebrew, and Dan. 2:4b-7:28 in Aramaic. The standard text of the Masoretic edition, Biblia Hebraica Stuttgartensia (Elliger and Rudolph 1983; Daniel is edited by W. Baumgartner), is based primarily upon the Leningrad 
Codex B 19A (dated to 1008-1009 CE). The $B H S$ apparatus also incorporates the manuscript evidence from the Cairo Geniza, along with variants collected by B. Kennicott (1783) and J.B. De Rossi (1784-87). The updated edition of Daniel in Biblia Hebraica Quinta (ed. by A. Schenker) is expected by 2020.

Although the primary manuscript evidence for the MT is rather late, most commentators view the biblical Daniel fragments discovered among the Dead Sea Scrolls as confirmation of the antiquity of this textual tradition (e.g., Collins 1993: 3). Seven fragmentary manuscripts were discovered among the caves1QDan ${ }^{\mathrm{a}-\mathrm{b}}, 4 \mathrm{QDan}{ }^{\mathrm{a}-\mathrm{d}}$, and 6QpapDan - in addition to a separate composition that probably contained only the prayer from Dan. 9:4b-19 (4QDan $\left.{ }^{\mathrm{e}}\right)$. These Daniel manuscripts preserve the shifts from Hebrew to Aramaic at Dan. 2:4b (1QDan ${ }^{\mathrm{a}}$ ) and back to Hebrew at ch. 8 (4QDan $\left.{ }^{\mathrm{a}}, 4 \mathrm{QDan}{ }^{\mathrm{b}}\right)$ as well as the absence of the Greek additions after ch. 3 (1QDan ${ }^{\mathrm{b}}$ and 4QDan ${ }^{\mathrm{d}}$ ). Further, there is no evidence of the other Greek additions in existence among the Dead Sea Scrolls (4Q551 was originally identified as 4QDaniel-Susanna, but this has been sufficiently refuted by Nickelsburg 1997). The Dead Sea Daniel manuscripts, however, do not align exactly with the MT, since they present many orthographic and phonological variants, as well as more significant departures that at times align with the OG or Theodotionic editions against that of the MT (see Ulrich 2002 for fuller discussion of the Daniel Dead Sea manuscripts).

\section{(2) Old Greek Edition}

The Old Greek edition of Daniel (OG) was probably one of the earliest translations of the book of Daniel into Greek (typically dated to the late second or early first century BCE; so Bludau 1897: 8; Montgomery 1927: 38; Hartman and DiLella 1978: 78; Collins 1993: 8-9). The primary edition of OG Daniel is that of Ziegler and Munnich, Susanna, Daniel, Bel et Draco (1999). The OG edition is sometimes referred to as the Septuagint. This designation, however, is problematic in discussing the book of Daniel, since it has been variously used to refer to both the OG and Theodotion versions of the book. Thus, OG is a more exact descriptor, referring to the earliest Greek edition of the book, and, to avoid confusion, it will be used throughout.

The dating of the OG edition of Daniel is typically rather early (i.e., shortly after the book's accepted date of composition) and it is possible that it was known by the author of 1 Maccabees (Henze 1999: 22-23; although Pace Jeansonne 1988: 16-18 and Koch 2002: 423-25 question this connection). By the time of the NT, it is likely that OG Daniel was widely known, as evidenced by its use in several NT texts (e.g., Mt. 24.30; Rev. 1.14; 4.1; 10.1, 5-6; 14.14-16; 20.12, 15). By the time of Jerome (fourth century $\mathrm{CE}$ ), however, this situation had greatly changed, and preference was instead given to Theodotion's version of Daniel (Swete 1902: 46-49; Montgomery 1927: 35-37; Braverman 1978: 15-16; DiLella 2002: 586-93). In his Commentary 
on Daniel, Jerome wrote that he could not explain how the text of 'the Seventy' came to be corrupted, but only that it was rightly rejected because it 'differed widely from the truth', that is the veritas hebraica (see Braverman 1978: 31).

The largely negative reception of the OG edition of Daniel in antiquity almost led to its complete disappearance. Until the eighteenth century, this edition was known only from a few references in various patristic writings. But then, two Hexaplaric manuscripts were discovered that included a column containing large portions of the text of OG Daniel: the Chigi Manuscript 88/Codex Chisianus (published by de Magistris 1772; dated ninth to eleventh centuries CE; incorrectly listed as MS 87 in Swete 1902: 47; this manuscript contains fragments of Origen's Hexaplaric recension of OG Daniel, including his Hexaplaric signs; now part of the Chigi collection that was transferred to the Vatican Library); and the Syro-Hexaplar Codex Ambrosianus (published by Ceriani 1874, fols 143a-151b; dated ninth century CE; the Syro-Hexaplar represents a highly literal translation of Origen's Hexaplaric text into Syriac and is attributed to the Monophysite bishop Paul of Tella in the years 616-17 CE). Based on Origen's Hexapla (completed around 240-45 CE), both the Chigi Manuscript and the SyroHexaplar are extremely problematic for reconstructing the text of OG Daniel because they are positioned according to the Masoretic order and thus contain frequent adaptations and transpositions (although they do include the Greek additions; see further DiLella 2002: 600-602). Only in the twentieth century did the first - and only - pre-Hexaplaric manuscript of OG Daniel surface: Papyrus 967 (discovered in 1931 in Egypt and dated around the late second century CE; Kenyon 1937; Geissen 1968; Hamm 1969; Roca-Puig 1976; Hamm 1977). This manuscript contains material from the OG edition of Daniel chs. 1-12 with the additions, as well as portions of Greek Ezekiel and Esther. One of the distinctive features of this manuscript is its order of material: it places chs. 7 and 8 before chs. 5 and 6, as well as 'Bel and the Dragon' before 'Susanna'. This is most likely an attempt by the editor to set the chapters of Daniel in better chronological order - chs. 7 and 8 set in the reign of Belshazzar precede ch. 5, which ends with his sudden death (see McLay 2005: 307-308). Others, however, have argued for the priority of the order preserved in Papyrus 967 (e.g., David 1991: 96-97; Lust 1993; Munnich 2003).

OG Daniel exhibits many notable divergences from the MT edition of the book. Foremost, it includes 'The Prayer of Azariah and the Song of the Three Youths' between Dan. 3:23 and v. 24, and 'Susanna' and 'Bel and the Dragon' after ch. 12. Additionally, the OG text often diverges from that of the MT, in both word and sentence order as well as in substance. This is especially the case in chs. 4-6, which do not exhibit consistent divergences when compared to the MT version of these chapters - OG chs. 4 and 6 are longer than those in the MT, while ch. 5 is considerably shorter in the OG than in MT. The OG edition of Daniel also differs greatly from the MT edition in numerous individual readings. 
While some commentators have suggested that the divergences in OG Daniel stemmed from the theological Tendenz of the Greek translator (e.g., Bruce 1977), others have suggested that most of the unique material in the OG edition of Daniel can be traced back to an underlying distinct Semitic Vorlagelikely Aramaic (Charles 1929: xlix-lxiv; Pace Jeansonne 1988; Wenthe 1991), although a Hebrew original has also been proposed (Grelot 1974a; 1974b; Haag 1983; Grelot 1995). Some clues offered as to the probable Semitic origins of the unique OG material include the use of parataxis and lack of Greek particles, suggesting a Semitic rather than a Greek style, as well as the use of vocabulary 'in a Semitic sense' (Collins 1993: 6; see also Montgomery 1927: 37). On the other hand, Bludau warned that one must also recognize 'the difficulty of distinguishing between Semitizing Greek and a translation of a Semitic Vorlage' (1897: 210; trans. Collins 1993: 6). Wenthe (1991) and Pace Jeansonne (1988) each conducted detailed studies on the translation technique of OG Daniel and arrived at the conclusion that it presents a 'reasonably accurate and faithful' translation of its Semitic original, albeit one seemingly unconcerned 'with standardizing roots or grammatical forms and [which] employs a much wider vocabulary' when compared with the translation technique of Theodotion Daniel (Pace Jeansonne 1988: 131, 133). In some instances the Dead Sea Daniel fragments may provide support for OG readings against those of MT and Theodotion-only once in chs. 4-6 (Dan. 5:7 in 4QDana) — but generally these are rather minor or insignificant and there is no evidence of the lengthy OG divergent readings.

\section{(3) Theodotionic Edition}

A second early translation of the book of Daniel is the so-called 'Theodotion' edition. At a very early stage, this edition of Daniel replaced that of the OG as the official version used by the early church. The Theodotionic edition was favored by the early church fathers since it more closely resembled the Masoretic version (see above). However, it too includes the Additions to Daniel-with 'Susanna' placed before the first chapter, the 'Prayer of Azariah and the Song of the Three Youths' serving as an appendix to ch. 3 and 'Bel and the Dragon' placed at the end of the book. This edition of the book of Daniel survives in most manuscripts of the Greek Old Testament, including in Codices Alexandrinus and Vaticanus, among others (Montgomery 1927: 26-27).

Theodotion Daniel is aptly named after a second-century CE person of that name. This Theodotion is reported to have completed a translation of the Hebrew Bible into Greek (cf. Irenaeus, Haer. 3.24 and Epiphanius, De mens. 17; see Montgomery 1927: 46-47). There is extensive evidence, however, that the Theodotionic edition of Daniel was used by both the New Testament authors and the early church fathers (e.g., Mt. 21.44; 28.3b; Jas 1.12; 1 Cor. 1.24; Heb. 11.33; Rev. 1.7a, 19; 9.20; 10.4-6; 11.7, 13; 12.7-8; 13.7; 16.18; 19.6; 20.4, 11; 
Herm. Vis. 4.2, 4; Justin, Dial. 31; Barn. 4.5; Bar. 1.15-2.19; Hippolytus, Comm. Dan.). Thus, dating would demand that this edition actually predates the historical person by probably two centuries. It is possible that the person Theodotion later reworked this earlier text, and it subsequently became associated with his name, so perhaps a better label would be 'Proto-Theodotion' (Pace Jeansonne 1988: 16-22).

The Theodotion edition of Daniel has also been linked with the kaige recension, named for its use of the Greek kaige for the Hebrew wegam (and also). The kaige recension is thought to be an extensive revision of the $\mathrm{OG}$ edition of the Hebrew Bible toward the MT or a Proto-Masoretic Hebrew text. It is primarily characterized by an extremely literal rendering of the Hebrew text into Greek, at times violating Greek style and syntax (Barthélemey 1953; Pace Jeansonne 1988: 20-22). Accordingly, Theodotion Daniel became associated with the kaige recension primarily due to its likewise apparent literal translation technique. This identification of this edition of Daniel and the larger kaige tradition, however, has been heavily contested (Schmitt 1966; Hartman and DiLella 1978: 81-82; McLay 1996: 219-40; DiLella 2002: 595-97).

\section{(4) Other Editions}

Two additional fragmentary Greek editions of the book of Daniel have also been identified. These are Aquila and Symmachus. Aquila's text is a slavishly literal translation of the MT. It is known primarily from Origen's Hexapla, but is also quoted several times by patristic authors. It is associated with a second-century CE person, who was said to be a proselyte to Judaism and student of the famous Rabbi Akiba (Epiphanius, De mens. 15; Irenaeus, Haer. 3.24). Symmachus, on the other hand, offers a much freer translation of the MT (yet certainly influenced by the OG and Theodotionic editions) in an elegant Greek style (see Metzger 1993). This work is credited to a person of the late second century CE, who was either an Ebionite Christian (Eusebius, Eccl. Hist. 6.17 and Jerome, Vir. ill. 54) or a Samaritan converted to Judaism (Epiphanius, De mens. 16).

\section{History of Scholarship on the Relationships of the Different Editions}

The relationship of the three editions of the book of Daniel-MT, OG, and Theodotion - has been disputed for more than two hundred years, and a scholarly consensus has not yet been reached. Initially, the OG edition faced intense bias from commentators, and was dismissed as secondary to both the Masoretic and Theodotionic editions of Daniel. At the end of the nineteenth century, the status quo was forcefully challenged and several new theories developed, which for the first time took seriously the merits of the OG edition. For clarity's sake, the 
relationship of the MT and OG editions of Daniel is typically treated separately from those editions and Theodotion, and I have retained that distinction here.

\section{(I) MT and OG}

Since antiquity, the Old Greek edition of Daniel had been considered inferior to the received text of the Hebrew/Aramaic Masoretic edition of the book (see discussion above). This negative opinion of OG Daniel continued even into the modern period, where for centuries it dominated the field of scholarship (see review of scholarship in Montgomery 1927: 35-37). It was not until the end of the nineteenth century that the merits of the OG edition were first taken seriously, and the debate over the relationship of the MT and OG editions of Daniel greatly shifted. Bludau (1897) first noted that, excluding the Greek additions, the differences between the OG and MT editions of Daniel were not evenly distributed throughout the book, but were primarily concentrated in chs. 4-6, and even there they were not consistent. Rather than simply dismissing the OG as secondary, however, this observation led Bludau to conclude that the MT and OG versions actually preserved two 'independent narratives of common content'. Thus, it represented an equally ancient text tradition and should be studied in its own right (1897: 31-33).

Building on Bludau's analysis, Montgomery (1927: 35-39) concluded there was no reason to assume that the divergences between the MT and OG editions stemmed from two distinct versions of the entire book of Daniel. Rather, he proposed that the concentration of the differences in chs. 4-6 indicated separate Vorlagen for these chapters only. He claimed that, at an early stage in the predevelopment of the book, these three chapters circulated as a collection of stories about the person Daniel, which only later attracted the additional stories and visions taking the shape of the contemporary book of Daniel (pp. 35-37).

A flurry of subsequent scholars also used Bludau's analysis to advocate instead for the priority of the OG edition over the MT. Many of these attempted to retrovert the OG text of Daniel into its Semitic (i.e., Hebrew!) Vorlage, and concluded from their analyses that the OG edition preserved a superior version of Daniel than that of the MT edition-for example, Riessler (1899) and Jahn (1904). Charles (1929) arrived at the same conclusion with regard to the status of OG Daniel, claiming that the Old Greek text preserved an 'earlier form of the Semitic text' of Daniel than the 'late redacted text of the MT' (p. lvii). Charles, however, offered a more nuanced view. Although he allowed that the OG text could make the 'greatest contribution to the recovery of the original text', particularly in chs. $4-6$, he suggested that the available manuscripts (i.e., Ms 88 and the Syro-Hexaplar) had been corrupted by later emendations (pp. 1-lxiv). Only a few years later, with the discovery of Papyrus 967, was Charles proved absolutely correct in this regard. 
These same debates over the relationship of the MT and OG editions of Daniel continue unabated into present scholarship, as proponents can still be found for each of the previous theories. In articulating their own particular position, the majority of scholars today follow the groundwork laid out by Bludau and Montgomery, although often in combination with elements from several of the other earlier theories.

Several modern scholars follow the classical position of the priority of the MT edition of Daniel over the OG edition. For example, Bruce considers the OG edition to be a 'targumic-style paraphrase' of the MT of Daniel (1977: 38). Another example is that of Grelot, who, following Riessler and Jahn, asserted that the OG edition was based on a Hebrew translation of the book carried out probably during the late Maccabean period (i.e., very shortly after the book's completion; see 1974a; 1974b; 1995). Conversely, though, he arrives at the opposite conclusion from his predecessors, claiming that 'there is no doubt' ('il n'est pas douteux') that the OG edition of Daniel is secondary in character when compared to the Aramaic edition of the book (1974b: 22). In his analysis of ch. 4 of Daniel, Satran likewise accepts the priority of the MT edition of the book over that of the OG, which he classifies as 'exegetical' and 'derivative' in nature (1985: 83; see further 62-94). However, he dismisses the idea that the OG stemmed from a divergent Semitic Vorlage or translation, and asserts that 'it appears unassailable that the Old Greek version reflects a Semitic reworking of the received Aramaic [i.e., Masoretic] text of Daniel ch. 4' (p. 83).

There has also been an attempt to revive the theory of the superiority of OG Daniel over the Masoretic edition. One example of this is the influential work of Wills (1990). In his careful comparison of the MT and OG editions of Daniel, Wills identifies several 'redactional traits' that he sees as indicative 'that the OG attests an older version of the legends [i.e., chs. 4-6]' than does the MT edition of Daniel (1990: 144; further, pp. 144-52). He continues by noting that the presence of these redactional traits in other parts of the book could indicate that chs. 4-6 'may very well have circulated together before being combined first with chs. 1-3 and then with 7-12 and the additions' (1990: 144; as proposed by Montgomery 1927: 88-99). Another scholar, Albertz, although likewise promoting the superiority of the OG edition of Daniel, distinctly argues against the circulation of chs. (3) $4-6$ as a separate unit. He rather suggests that Daniel 2-7 comprises a distinct literary unit that was probably 'composed and written by one author' who assembled his collection by combining the individual stories in circulation with the first apocalyptic vision (2002: 178; following Kratz 1993). He concludes, therefore, that these chapters in the OG 'are not late and inaccurate midrashim as is often thought, but represent an independent shape of the Daniel stories which in my view is even older than the Aramaic, perhaps not in all their details, but in their basic narrative plot' (2002: 180, further pp. 179-83; 1988: 13-42, 77-84, 113-28). 
The majority of recent commentators, however, judge as too simplistic an approach that designates one edition as 'original' and the other as derivative, especially in light of the divergences in the form of chs. 4-6 in the Masoretic and OG editions. These scholars, then, follow Bludau or Montgomery in postulating separate Vorlagen as accounting for the numerous differences between the two editions. Like Bludau, Meadowcroft argues that the deviations between the MT and OG editions of Daniel are the result of divergent Semitic Vorlagen, although he amends this view slightly by suggesting that disparities also arose from the act of translation. He claims that the OG translator likely attempted to render its Vorlage in a rather literal manner but, nevertheless, changes crept in because of the 'disparity in the semantic range between languages' as well as the translator's attempts 'to clarify what he sees as a difficulty in the Aramaic text', resulting in both technical and theological alterations (1995: 262-63; contra Pace Jeansonne, who asserts there is no theological Tendenz in the OG translation, 1988: 131). Meadowcroft concludes by asserting the possibility that the OG Vorlage predates (only slightly) the Masoretic form of the Hebrew/Aramaic text of Daniel 2-7, since it appears to him that the OG translator 'was limited by a less polished Vorlage than the MT' ( $p$. 266). Thus, he suggests that the 'translation [of the OG] may have taken place very close to when the MT reached its present form' (p. 274).

More commentators today, however, follow Montgomery's work, supposing that different Vorlagen were used only in chs. 4-6 (e.g., Collins 1993: 5-6; DiLella 2002: 604; Koch 2002: 425-27). Contrary to Meadowcroft, then, they support the order of material in the Masoretic edition, since it presents these chapters consecutively.

The most comprehensive reassessment of this theory is that of Ulrich, who has coined the term 'double literary editions' to describe a textual phenomenon such as that observed in the MT and OG editions of Daniel. This term is defined as

a literary unit appearing in two (or more) parallel forms in our principal textual witnesses, which one author, major redactor, or major editor completed and which a subsequent redactor or editor intentionally changed to a sufficient extent that the resultant form should be called a revised edition of that text. (1999: 102)

Other examples of this phenomenon include the book of Jeremiah, the Deuteronomistic History, or the story of David and Goliath, among others. Ulrich proposes that in the case of Daniel 4-6, both the MT and the OG editions are apparently secondary; that is, we have two revised editions with each 'expand[ing] in different directions beyond an earlier common edition that no longer survives' (1999: 40). Thus, each of these editions preserves some earlier readings alongside other later ones as a result of the work of multiple redactors, editors, or translators. 
Ulrich has directed two dissertations examining the translation technique employed in OG Daniel (Pace Jeansonne 1988 and Wenthe 1991), both of which conclude that the OG translation accurately conveys the Semitic text, though it sometimes adds explanatory glosses or even paraphrases. Ulrich suggests, then, that chs. 4-6 in the OG 'appear to be woven from the same fabric as the OG translation of 1-[3] and 7-12', and OG Daniel, as a whole, 'seems to be a consistent, unified document with a consistent translation technique' (Ulrich 1999: 45; see also Montgomery 1927: 36-37; Meadowcroft 1995: 263). Thus, the differences in OG chs. 4-6 were made early on at the Aramaic level, and were later translated into Greek (Ulrich 1999: 45; see also Montgomery 1927: 248).

Ulrich's theory, however, has not won universal support. McLay rejects Ulrich's conclusions (as well as those of Pace Jeansonne and Wenthe) regarding a consistent translation technique for the OG edition of Daniel. He rather proposes that chs. 4-6 were translated into Greek very early on. This unit of stories was probably widely circulated in the Greek-speaking diaspora, and when the larger collection of Daniel stories and visions was compiled in Hebrew/Aramaic, a subsequent translator completed the full OG translation of the book, replacing the text of chs. 4-6 with the earlier Greek translation. McLay estimates that this would have occurred shortly after 167 BCE (2005: 320).

\section{(2) Theodotion in Relation to the MT and OG}

Just as there is no consensus regarding the relationship between the MT and OG editions of Daniel, there is also no general agreement for how Theodotion relates to these two editions. The text of Theodotion Daniel generally aligns nearly word for word with that of the MT; when Theodotion does depart from the text of the MT, it usually matches the reading of the OG. In some instances, however, Theodotion departs from both the MT and OG (particularly in ch. 3, so Meadowcroft 1995: 282-85; further, see discussion above). Since it is typically assumed that Theodotion is later than either of the other versions (see above), there are several possible options for how it relates to the MT and OG: Theodotion is viewed primarily as a translation of MT Daniel, or as a recension of OG Daniel toward the text of the MT. More recently, it has also been conjectured that Theodotion could represent a separate Vorlage independent from the other editions. Further, the Greek additions in ch. 3 ('The Prayer of Azariah and the Song of the Three Youths') are almost identical in the two editions, while 'Susanna' and 'Bel and the Dragon' display greater divergences.

Early opinions, tracing back to the time of the early church fathers, regarded Theodotion as a precise translation of the Hebrew/Aramaic text of Daniel, while the OG was considered a less exact, even paraphrastic translation. With Bludau's work (1897) and the major change in opinion concerning the dating and authority of OG Daniel, however, its relationship to Theodotion was reassessed. By the time of Montgomery's commentary (1927), attitudes had so greatly shifted 
that Montgomery concluded Theodotion was ultimately dependent on OG Daniel, which was probably already held as authoritative at a very early point in some Greek-speaking Jewish communities. He accounted for the convergences between Theodotion and MT Daniel, however, by claiming that Theodotion has greatly redacted the OG text toward that of the Hebrew/Aramaic MT (1927: 39-42). This explanation allowed for the presence of the Greek Additions in both Theodotion and OG yet lacking from MT.

Montgomery's view enjoyed large popularity, and even today has many adherents (see, e.g., Satran 1985: 68; Bogaert 1993; Collins 1993: 11; Munnich 1995a; Pace Jeansonne 1988). It is also this proposed relationship to MT and OG that has led scholars to connect the Theodotionic Daniel edition with the kaige recension (Barthélemey 1953). This view has also recently been stated by DiLella, who asserts, 'What is beyond question is that OG Daniel is prior to Theodotion Daniel, for the latter presupposes the former' (2002: 590-91). He amends Montgomery's theory, however, to indicate that the base text of Theodotion was the MT rather than the OG edition of Daniel. 'The translator [of Theodotion Daniel] was of the opinion that OG-Dan did not accurately render the Hebrew and Aramaic original; so he translated the work anew with an eye, however, on OG-Dan' (p. 596; also Hartman and DiLella 1978: 82). This better accounts for the readily apparent divergence in translation technique employed between the respective translators of the OG and Theodotionic editions.

Other commentators do not accept the notion that at the turn of the common era there was a tendency for Greek translators to correct the OG editions of books on the basis of the Hebrew texts. These scholars continue to understand Theodotion Daniel as older and superior to OG Daniel, and maintain support for the earliest theory that Theodotion was a direct translation of the Hebrew/ Aramaic text (see, e.g., Bruce 1977).

More recently, a new approach to understanding the relationship of Theodotionic Daniel to the MT and OG editions of the book has been suggested. This theory largely understands the Theodotion and OG editions of Daniel as stemming from independent Vorlagen, with that of Theodotion being much closer to the text of MT Daniel. The strongest advocate of this theory is McLay (1996; see also Meadowcroft 1995: 281-88), who proposes that a close study of the two major Greek editions of Daniel does not necessarily indicate dependence, as many scholars would assume, but rather different translation techniques. He believes that the OG edition of Daniel represents a more dynamic approach, while Theodotion has 'formal equivalence' (pp. 211-12). McLay remarks that

Generally, there is very little relationship between the two Greek versions in chapters $1-6(7)$, because their origins are chronologically and geographically distinct and their core translations were based on different Vorlagen ... Chapters (7)8-12 are based on very similar Vorlagen and were translated much closer in time. (2005: 323) 
Rather than viewing the commonalities between Theodotionic and OG Daniel as evidence that Theodotion was a recension of the OG text, McLay proposes instead that the OG text was actually corrupted by Theodotion (p. 217). Thus, although in some portions of Theodotionic and OG Daniel the verbal agreements between the two texts may seem to suggest that one is a revision of the other, this is not really the case (2005: 323$)$.

\section{Concluding Remarks}

Although the negative view of the OG edition of Daniel has been seriously challenged since the late nineteenth century, and in the past thirty years there has been an increasing number of studies on this edition of the biblical book, OG Daniel is still largely neglected in broader scholarship and even more so in the public sphere. Some examples of this are the host of commentaries that only treat the Masoretic edition of the book, with merely a few notes about the OG edition of Daniel (e.g., Goldingay 1996; Pace Jeansonne 2008), or in studies of the Dead Sea Scrolls Daniel, where the MT is still treated as the standard text of comparison. Nevertheless, a huge step forward is the rather recently published NETS edition of both OG and Theodotion Daniel (McLay 2007/2009), which make the editions of Daniel readily available to the public and scholars alike.

In his article, DiLella rightly summarizes,

The Greek forms have great value for their own sake even without reference to the parent text(s). Hence, they have intrinsic value and should be studied on their own, and not just as a means to correct or improve the Hebrew and Aramaic texts that served as their respective Vorlagen. (2002: 605)

\section{Bibliography}

Albertz, R.

1988 Der Gott des Daniel: Untersuchungen zu Daniel 4-6 in der Septuagintafassung sowie zu Komposition und Theologie des aramäischen Danielbuches (SBS, 131; Stuttgart: Katholisches Bibelwerk).

2002 'The Social Setting of the Aramaic and Hebrew Book of Daniel', in Collins and Flint (eds.) 2002: 1.171-204.

Barthélemey, D.

1953 'Récouverte d'un chaînon manquant de l'histoire de la Septante', $R B$ 60: 18-29.

Baumgartner, W. (ed.)

1983 'Daniel', in Elliger and Rudolph (eds.) 1983.

Bludau, A.

1897 Die alexandrinsiche Übersetzung des Buches Daniel und ihr Verhältniss zum massorethischen Text (BibS[F], 2.2.3; Freiburg: Herder).

Bogaert, P.-M.

1993 'Daniel 3 LXX et son supplément grec', in van der Woude (ed.) 1993: 13-37. 
Braverman, J.

1978 Jerome's Commentary on Daniel: A Study of Comparative Jewish and Christian Interpretations of the Hebrew Bible (CBQMS, 7; Washington DC: CBAA).

Bruce, F.F.

1977

'The Oldest Greek Version of Daniel', in H.A. Brongers et al. (eds.), Instruction and Interpretation: Studies in Hebrew Language, Palestinian Archaeology, and Biblical Exegesis (OtSt, 20; Leiden: Brill) 22-40.

Ceriani, A.M.

1874 Codex syro-hexaplaris Ambrosianus photolithographice editus (Monumenta sacra et profana, 7; Milan: Pogliani).

Charles, R.H.

1929 A Critical and Exegetical Commentary on the Book of Daniel (Oxford: Oxford University Press).

Collins, J.J.

1993 Daniel: A Commentary on the Book of Daniel (Hermeneia; Minneapolis: Fortress Press).

Collins, J.J., and P.W. Flint (eds.)

2002 The Book of Daniel: Composition and Reception (2 vols; VTSup, 83; Leiden and Boston: Brill).

Cross, F.M.

1956 'Editing the Manuscript Fragments from Qumran: Cave 4 of Qumran (4Q)', BA 19: 75-96.

David, P.S.

1991 'The Composition and Structure of the Book of Daniel: A Synchronic and Diachronic Reading' (Ph.D. dissertation, Katholieke Universiteit Leuven).

Davies, P.R.

1998 Daniel (OTG; Sheffield: Sheffield Academic Press).

De Rossi, G.B.

1784-88 'Variae Lectiones in Veteris Testament' (Parma).

1795-99 'Annales Hebræo-Typographici ab 1501 ad 1540' (Parma).

DiLella, A.A.

2002

'The Textual History of Septuagint-Daniel and Theodotion-Daniel', in Collins and Flint (eds.) 2002: 2.586-607.

Dines, J.

2007 'The King's Good Servant? Loyalty, Subversion, and Greek Daniel', in T.S.

Rajak et al. (eds.), Jewish Perspectives on Hellenistic Rulers (HCS, 50;

Berkeley and Los Angeles: University of California) 205-24.

Dorival, G., and O. Munnich (eds.)

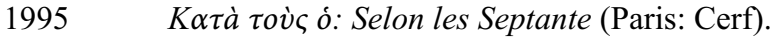

Elliger, K., and W. Rudolph (eds.)

1983 Biblia Hebraica Stuttgartensia (5th edn, 1997; Stuttgart: Deutsche Biblische Gesellschaft).

Eusebius of Caesarea

1932 Ecclesiastical History: Books VI-X (trans. J.E.L. Oulton; LCL; Cambridge, MA: Harvard University Press). 
Geissen, A.

1968 Der Septuaginta-Text des Buches Daniel, Kap. 5-12, zusammen mit Susanna, Bel et Draco, nach dem Kölner Teil des Papyrus 967 (PTA, 5; Bonn: R. Habelt).

Goldingay, J.E.

1996 Daniel (WBC, 30; Nashville: T. Nelson).

Grelot, P.

1966 'Les versions grecques de Daniel', Bib 47: 381-402.

1974a 'Le chapitre V de Daniel dans la Septante', Sem 24: 45-66.

1974b 'La Septante de Daniel IV et son substrat sémitique', RB 81: 5-23.

1995 'Daniel VI dans la Septante', in Dorival and Munnich (eds.) 1995: 103-18.

Haag, E.

1983 Die Errettung Daniels aus der Löwengrube: Untersuchungen zum Ursprung der biblischen Danieltradition (SBS, 110; Stuttgart: Katholisches Bibelwerk $\mathrm{GmbH})$.

Hamm, W.

1969 Der Septuaginta-Text des Buches Daniel, Kap. 1-2, nach dem Kölner Teil des Papyrus 967 (PTA, 10: Bonn: R. Habelt).

1977 Der Septuaginta-Text des Buches Daniel, Kap. 3-4, nach dem Kölner Teil des Papyrus 967 (PTA, 21; Bonn: R. Habelt).

Hartman, L.F. and A.A. DiLella

1978 The Book of Daniel (AB; Garden City, NY: Doubleday).

Henze, M.

1999 The Madness of King Nebuchadnezzar: The Ancient Near Eastern Origins and Early History of Interpretation of Daniel 4 (JSJSup, 61; Leiden and Boston: Brill).

Jahn, G.

1904 Das Buch Daniel nach dem Septuaginta hergestellt (Leipzig: Pfeiffer).

Kennicott, B.

1776-80 Vetus Testamentum hebraicum cum variis lectionibus.

1783 Dissertatio Generalis in Vetus Testamentum Hebraicum (Brunswick: Paulus Jacobus Bruns).

Kenyon, F.G.

1937 The Chester Beatty Biblical Papyri: Descriptions and Texts of Twelve Manuscripts on Papyrus of the Greek Bible (8 vols; London: E. Walker).

Koch, K.

1980 Das Buch Daniel (EdF, 144; Darmstadt: Wissenschaftliche Buchgesellschaft).

1987 Deuterokanonische Zusätze zum Danielbuch (AOAT, 38/1.2; Neukirchen: Neukirchener Verlag).

2002 'Stages in the Canonization of the Book of Daniel', in Collins and Flint (eds.) 2002: 2.421-46.

Koch, K., and M. Rösel (eds.)

$2000 \quad$ Polyglottensynopse zum Buch Daniel (Neukirchen: Neukirchener Verlag).

Kratz, R.G.

1993 'Reich Gottes und Gesetz im Danielbuch und im werdenden Judentum', in van der Woude (ed.) 1993: 435-79. 
Lust, J.

1993 'The Septuagint Version of Daniel 4-5', in van der Woude (ed.) 1993: 41-53. Magistris, S. de

1772 Daniel secundum Septuaginta. ex tetraplis Origenis nunc primum editus e singulari Chisiano codice (Rome: Typis Propagandae Fidei).

McLay, R.T.

1996 The OG and Th Versions of Daniel (SBLSCS, 43; Atlanta: Scholars Press).

1998 'It's a Question of Influence: The Theodotion and Old Greek Texts of Daniel', in A. Salvesen (ed.), Origen's Hexapla and Fragments: Papers Presented at the Rich Seminar on the Hexapla, Oxford Centre for Hebrew and Jewish Studies, 25th July-3rd August 1994 (TSAJ, 58; Tübingen: Mohr Siebeck) 231-54.

2005 'The Old Greek Translation of Daniel IV-VI and the Formation of the Book of Daniel', VT 55: 304-23.

2007/2009 Translation of Daniel, in Pietersma and Wright (eds.) 2007/2009.

Meadowcroft, T.J.

1995 Aramaic Daniel and Greek Daniel: A Literary Comparison (JSOTSup, 198; Sheffield: Sheffield Academic Press).

Metzger, B.M.

1993 'Theories of the Translation Process', BSac 150: 140-50.

Montgomery, J.A.

1927 A Critical and Exegetical Commentary on the Book of Daniel (ICC; New York: Scribner).

Munnich, O.

1995a 'Les nomina sacra dans les versions grecques de Daniel et leurs supplements deuterocanoniques', in Dorival and Munnich (eds.) 1995: 145-67.

1995b 'Les versions grecques de Daniel et leurs substrats sémitiques', in L. Greenspoon and O. Munnich (eds.), VIII Congress of the International Organization for Septuagint and Cognate Studies, Paris 1992 (SBLSCS, 41; Atlanta: Scholars Press) 291-308.

2003 'Texte massorétique et Septante dans le livre de Daniel', in A. Schenker (ed.), The Earliest Text of the Hebrew Bible: The Relationship between the Masoretic Text and the Hebrew Base of the Septuagint Reconsidered (SBLSCS, 52; Atlanta: Society of Biblical Literature) 93-120.

Nickelsburg, G.E.

1997 '4Q551: A Vorlage to Susanna or a Text Related to Judges 19?', JJS 48: 349-51. Pace Jeansonne, S.

1988 The Old Greek Translation of Daniel 7-12 (CBQMS, 19; Washington, DC: CBAA).

2008 Daniel (Smith and Helwys Bible Commentary; Macon, GA: Smith and Helwys).

Pietersma, A., and B.G. Wright (eds.)

2007/2009 New English Translation of the Septuagint (NETS) (New York: Oxford University Press).

Riessler, P.

1899 Das Buch Daniel: Textkritische Untersuchung (KKHSAT, 3.3.2; Stuttgart und Wien: Roth). 
Roca-Puig, R.

1976 'Daniele: Due semifogli del codice 967, P. Barc. inv. nn. 42 e 43', Aeg 56: 3-18.

Rossi, G.B. de

1784-87 Variae lectiones Veteris Testamenti, ex immensa mss. editorumque codicum congerie haustae et ad samar. textum, ad vetustiss. versiones, ad accuratiores sacrae criticae fontes ac leges examinatae. Ejusdem scholia critica in V.T. libros, seu supplementa ad Varias sacri textus lectiones (5 vols.; Parma: Regio Typographeo).

Satran, D.

1985 'Early Jewish and Christian Interpretation of the Fourth Chapter of the Book of Daniel' (Ph.D. dissertation, Hebrew University).

Schmitt, A.

1966 Stammt der sogenannte 'Th' Text bei Daniel wirklich von Theodotion? (MSU, 9; Göttingen: Vandenhoeck \& Ruprecht).

1992 'Die griechischen Danieltexte und das Theodotionsproblem', BZ 36: 1-29.

Swete, H.B.

1902 An Introduction to the Old Testament in Greek (Cambridge: Cambridge University Press).

Ulrich, E.

1999 'Double Literary Editions of Biblical Narratives and Reflections on Determining the Form to be Translated', in The Dead Sea Scrolls and the Origins of the Bible (SDSSRL; Grand Rapids: Eerdmans) 34-50. Repr. in J.L. Crenshaw (ed.), Perspectives on the Hebrew Bible: Essays in Honor of Walter J. Harrelson (Macon, GA: Mercer University, 1988) 101-16.

2002 'The Text of Daniel in the Qumran Scrolls', in Collins and Flint (eds.) 2002: 2.573-84.

2011 'The Parallel Editions of the Old Greek and Masoretic Text of Daniel 5', in S.I. Thomas, A. Schofield and E. Ulrich (eds.), A Teacher for All Generations: Essays in Honor of James C. VanderKam (2 vols; JSJSup, 153; Leiden and Boston: Brill) 1.201-17.

Van der Woude, A.S. (ed.)

1993 The Book of Daniel in the Light of New Findings (BETL, 106; Leuven: Leuven University Press).

Wenthe, D.O.

1991 'The Old Greek Translation of Daniel 16' (Ph.D. dissertation, University of Notre Dame).

Wills, L.M.

1990 The Jew in the Court of the Foreign King: Jewish Court Legends (HDR, 26; Minneapolis: Fortress).

Ziegler, J., and O. Munnich (eds.)

1999 Susanna, Daniel, Bel et Draco (Septuaginta: Vetus Testamentum Graecum, 16.2; Göttingen: Vandenhoeck \& Ruprecht, 2nd edn [1968]). 